\title{
Examining the Relationships between Properties of Atmospheric Precipitates (Rain and Dew Water) and Emitted GHGs across the Different Land Use Types in Port Harcourt Metropolis
}

\author{
A. Obisesan (Corresponding) \\ Department of Geography and Environmental Management, Faculty of Social Sciences \\ University of Port-Harcourt, Choba, Rivers State, Nigeria \\ Tel: 234-803-707-6291Ｅ-mail: Kundekash@gmail.com
}

\author{
M. O. Nwagbara \\ Department of Soil Science and Meteorology \\ Michael Okpara University of Agriculture, Umudike, Abia State, Nigeria
}

Tel: 234-810-635-2814Ｅ-mail: monwagbara@gmail.com

Received: August 19, 2019 Accepted: September 6, 2019 Published: September 11, 2019 doi:10.5296/emsd.v8i4.15425

URL: https://doi.org/10.5296/emsd.v8i4.15425

\begin{abstract}
In this study, the researchers examine the relationships between contaminants found in rain and dew water and the greenhouse gases emitted in Port Harcourt. The quasi experimental research design was used to carry out the study. Primary data of rain and dew water, and GHGs amounts were collected directly by the researcher at designated sampling points in Port Harcourt metropolis for a period of one year. The Pearson's product moment correlation coefficient was used for data analysis in the environment of the IBM/statistical package for the social sciences (IBM/SPSS). Results obtained showed that GHGs amounts across the various land uses were higher than World Health Organisation (WHO) standards for all the gases examined. Alsot the land uses that ought to generate the GHGs, such as the residential and urban land-uses had lower emission rates than thick vegetation and fresh water land uses. The correlation coefficients between the gases and the atmospheric precipitates show that, there are positive relationship between gas emission and contaminates in rain and dew water
\end{abstract}


at $\mathrm{P}<0.05$. Also, volatile organic compounds (VOCs), had inverse relationships in some instances, revealing the influence of other atmospheric controls such as wind speed and direction. Following these findings, the study recommends that, locals abstain from rainfall, boil harvested rainwater before use for domestic purposes, and laws be both enacted and enforced to reduce pollution rates in the metropolis and adjoining areas.

Keywords: Rain-water, Dew-water, Volatile Organic Carbon, Land-use, Greenhouse gases

\section{Introduction}

There is rising unease over the dynamics of fresh water resources and how they affect daily life and survival of many people (Vuollekoski et al., 2015). What has been established in literature is that over 1 billion persons in less developed countries are already lacking adequate access to water (United Nations, 2006) and the number is expected to increase to about 3 billion by 2025 due to the rapid increase of population (Vuollekoski et al., 2015).

Water resources can either be found as ground water, surface water (rivers, lakes, seas, and oceans), glaciers, snow, or soil and air moisture and in dew form. Fessehaye et al. (2014) explained that dew is a highly local phenomenon that occurs when moist air is cooled by the emission of long-wave radiation or by forced ascent up a mountain slope and that the decrease in temperature cause super-saturation. More importantly, dew is the moisture which condenses from the atmosphere on plants, soil, or other surfaces near the ground (Vuollekoski etal., 2015); though the formation of dew by volume is a very slow process compared to the formation of fog; but experience shows that, dew forms primarily during the early morning hours when the temperature approaches its minimum diurnal value and that dew formation is also a local phenomenon, significantly influenced by microclimatic environment, land profile, and favourable meteorological conditions (Xu, Zhu, Tang \& Lin, 2015). However, dew forms in the early evening also and probably this continues throughout the night, though the rate of formation decreases because the layer of air closest to the ground becomes saturated. The vapour pressure gradient at the immediate surface of ground nearly becomes zero because of lack of mixing in the lowest layers. Dew is the outcome of a process whereby atmospheric vapour condenses on a substrate as result of radiative cooling (Beysens, Ohayon, Muselli \& Clus, 2006). Beysens et al., (2006) reported that unlike rain and fog which are known to be atmospheric precipitations, dew forms on a surface and the yield of dew water is very dependent on the nature and environment and the condensing substrate materials and condenser design. Furthermore, shallow rooted plants make use of dew water as the moisture from the dew penetrates only a thin layer of soil and evaporates quickly when the sun begins to warm the surface. On the other hand, more than $90 \%$ precipitation falls from clouds water and crystals of ice (mixed clouds) (Kidron \& Starinsky, 2012) with its roles played by the dynamic factors which include vertical motions, advective and turbulent inflows of heat and water vapour. The precipitation is observed to be in form of rain, snow, Graupel and hail. Rainwater is not only useful for domestic purposes but can also be used for agricultural and industrial purposes because of their applications that require heavy water use (United Nations Environment Programmes (UNEP, 2009; Dirinfo et al, 2010; Mackay et al, 2010; Jayaraman, 2007; chauhan et al., 2010; Dominick et al, 2012). 
The quest to consider dew water and rainwater as potable water to mankind has been on ground for long. Inadequacy of potable water is a huge challenge in many regions of the world in which the Niger Delta of Nigeria is inclusive. Groundwater and surface water are becoming too dangerous for consumption in recent times in many communities especially the coastal ones and crude oil producing communities due to the exploration of oil in those communities. Rainwater has been in use everywhere in the developing countries with rare investigations of elemental compositions that meet the potability standards of WHO. Consequently, dew water yield is less studied in Nigeria perhaps due to finance or less interest about the usefulness of the precipitation type. Beysens etal., (2009) agreed that dew and rain water in the Mediterranean Dalmatian coast and Islands of Croatia meet in average the WHO requirements for potable water especially when considered as spring water. The investigations regarding the dew and rain water with respect to the local meteorological parameters and air qualities in varying ecological zones can be of immense use to determining the yield and quality of the rain and dew water. Dew is in essence distilled water and thus should not be, a priori, contaminated by heavy metals and dangerous bacteria, unless dew can absorb and dissolve the atmospheric gases around and the aerosols captured by the substrate.

Nevertheless to the best of the knowledge of the researchers, the quality of rain and dew water which are influenced by air quality and weather parameters are yet to be determined especially at different land-use types in Port Harcourt Metropolis; even though the air quality characteristics have be investigated in several studies ( Eludoyin \& Akinola, 2015; Eludoyin, Oderinde \& Azubuike, 2013; Mmom, \& Fred-Nwagwu, 2013; Weli, 2014) and the findings include, the air quality in the area (Port Harcourt) has been polluted dangerously. This study examines the relationships between properties of atmospheric precipitates (rain and dew water) and emitted GHGs (which have been identified to be high in the study area) across the different land use types in Port Harcourt metropolis.

\section{Materials and Methods}

The study area is Port Harcourt Metropolis, Rivers State, Nigeria. The study location is found between latitudes $4^{\circ} 51^{\prime} 30^{\prime \prime} \mathrm{N}$ and $4^{\circ} 57^{\prime} 30^{\prime} \mathrm{N}$ and longitudes $6^{\circ} 50^{\prime} 00^{\prime} \mathrm{E}$ and $7^{\circ} 00^{\prime} 00^{\prime \prime} \mathrm{E}$ (Figure 1). Port Harcourt Metropolis is the capital city of Rivers State. Rivers State was established on May 27, 1967. It came into being due to the dissolution of the old structure in Nigeria. Rivers State bounded on the south by the Atlantic Ocean, west by Bayelsa and Delta States, north by Imo, Abia and Anambra States and east by Akwa Ibom State. Rivers State has twenty three local government areas presently. 


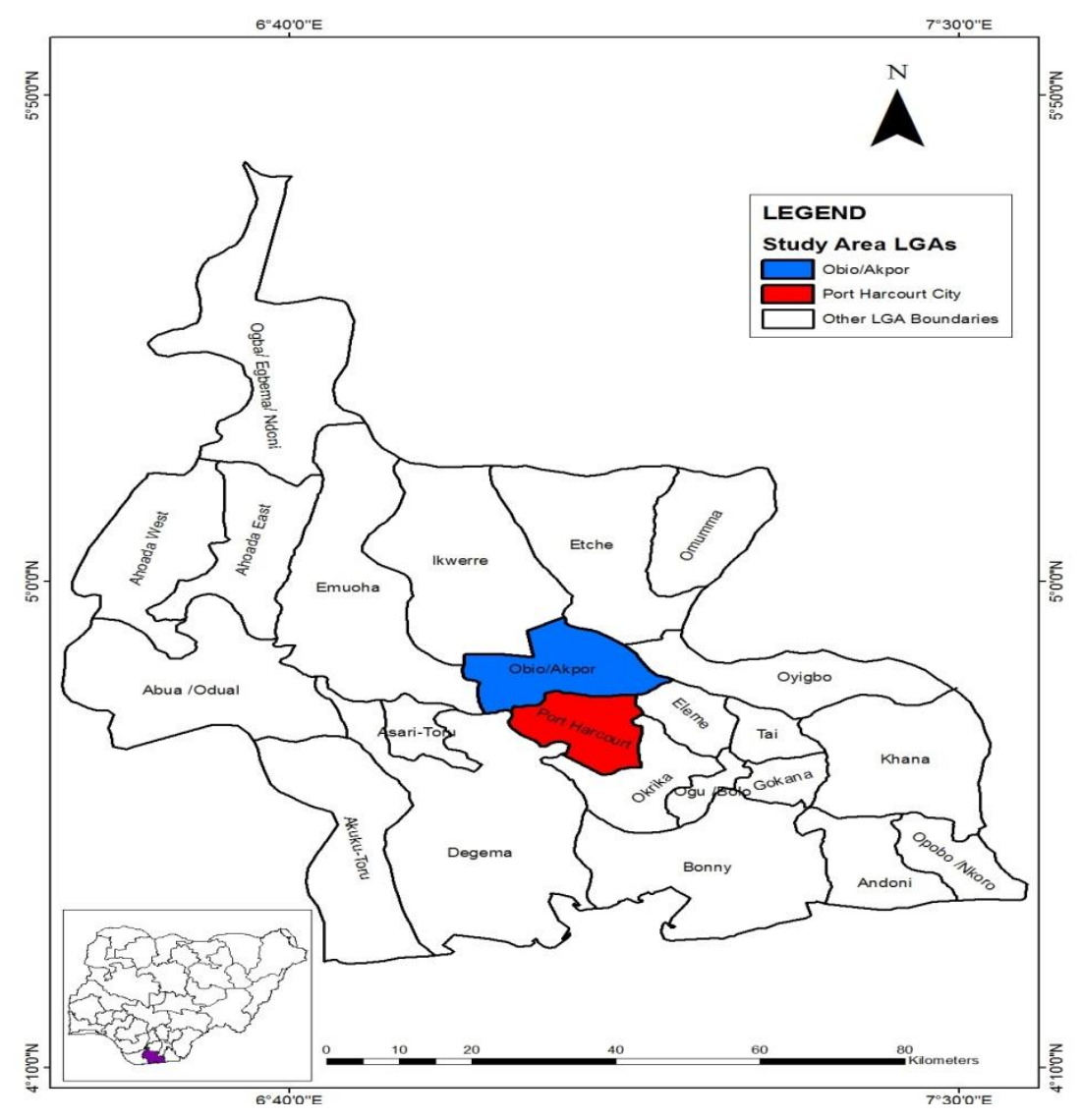

Figure 1. Rivers State showing study area

The study area is underlain by the Coastal Plain sands having its place from the Pleistocenic Formation (Efe, 2002). The sediments are deposits comprising of gravel, clays, peats, sands and silt from the River Niger (Efe, 2005). The depositional order displays vast sandstones superimposing an interchange of sandstones and clays of slightly marine source which has developed to be marine clays. (Efe, 2009). The topography in the uplands ranges between 15 and $40 \mathrm{~m}$ above the sea level while the mean elevation of about $15 \mathrm{~m}$ is found in the riverine areas (Efe, 2009). The study area which is situated in the Niger Delta region has a relatively flat terrain with marked absence of hills that rise above the general land surface (Efe, 2002). This makes pollution effects in the area very pervasive.

Port Harcourt Metropolis is found in the sub-equatorial region. It has a tropical climate with a mean temperature of $30^{\circ} \mathrm{C}$ a relative humidity of $80 \%-100 \%$, and a mean yearly rainfall of about 2,300mm (Mmom \& Fred-Nwagwu, 2013). The warmest months are from January to May, and all have more than 20 days with a temperature of $32^{\circ} \mathrm{C}$ or above, however, the tropical climate is moderated by the influence of the Atlantic Ocean. The area is also characterized by heavy rainfall from April to October ranging from $2000 \mathrm{~mm}$ to $2500 \mathrm{~mm}$.

Tropical rainforest is found in the inland part of Rivers State and mangrove swamps towards the coast the Atlantic Ocean. The vegetation represents the most luxuriant, the most complex, and the most diverse terrestrial ecosystem the world has known (Eludoyin etal., 2013). 


\section{Macrothink}

Unfortunately, much of the rainforest has been destroyed as a result of farming, commercial lumbering and urbanization.

As for methods, the quasi experimental research design was used to carry out the study. Primary data of rain and dew water, and GHGs amounts were collected directly by the researcher at designated sampling points in Port Harcourt metropolis for a period of one year.

The sampled locations were selected based on land-use types using stratified random sampling technique. This sampling technique was used because it has high statistical precision and the variability within the subgroups is lower compared to the variations when dealing with the entire population (Singh, Rao \& Khan, 2014). The major land-use types of Port Harcourt Metropolis made use of include thick vegetation, built up area, sparse vegetation/farmland and fresh water swamp (Eludoyin \& Akinola, 2015). The built up area were further divided into industrial, commercial, residential (low and high) and peri urban/rural land-use types this calibration has also been used by Weli, (2014). The area in square kilometre generated in the study of Eludoyin and Akinola (2015) was used to proportionally generate the number of sampling locations for the study. The land-use types in the built up area were given equal treatment by giving each land-use type equal number of sampling locations. In order to select the sample points which served as study monitoring stations for rain and dew water; air quality parameters. However, $5 \%$ of the total grids in each land-use type were randomly selected for the data collection. As a result, the number of sampling locations with respect to each land-use is as given in Table 3.1 wherein 22 sampling stations were derived. The latitudes and longitudes sampling stations were then obtained with the aid of a GPS.

Table 1. Sampling Locations across Different Land-use Types in Port Harcourt Metropolis

\begin{tabular}{|c|c|c|c|c|}
\hline Land-use types & Sub Divisions & $\begin{array}{l}\text { Area } \\
(\text { Sq. km) }\end{array}$ & $\begin{array}{l}\text { No of Possible Sampling Locations } \\
\text { based on } 1000 \mathrm{~m} \times 1000 \mathrm{~m} \text { Grid }\end{array}$ & $\begin{array}{l}5 \% \text { of the } \\
\text { Sampling } \\
\text { Locations }\end{array}$ \\
\hline Thick vegetation & & 81.76 & 82 & 4 \\
\hline \multirow[t]{5}{*}{ Built up area } & Commercial & \multirow[t]{5}{*}{205.89} & \multirow[t]{5}{*}{206} & 2 \\
\hline & Industrial & & & 2 \\
\hline & Peri-Urban/Rural & & & 2 \\
\hline & Low Residential & & & 2 \\
\hline & High Residential & & & 2 \\
\hline Fresh water swamp & & 42.70 & 43 & 2 \\
\hline Farmland/Sparse vegetation & & 111.55 & 112 & 6 \\
\hline Total & & & & 22 \\
\hline
\end{tabular}

The Pearson's product moment correlation coefficient (PPMC) was used for data analysis in the environment of the IBM/statistical package for the social sciences (IBM/SPSS); while presentation of data was achieved using tables. 


\section{Macrothink}

Table 2. Average annual physical and chemical characteristics of rain and dew water in different land-use in Port Harcourt Metropolis

\begin{tabular}{|c|c|c|c|c|c|c|c|c|c|c|c|c|c|c|c|c|c|c|}
\hline \multirow[t]{2}{*}{ Land use } & \multicolumn{15}{|c|}{ Chemical Properties } & \multicolumn{3}{|c|}{ Physical Properties } \\
\hline & $\mathrm{Cu}$ & $\mathrm{Mg}$ & $\mathrm{K}$ & $\mathrm{Na}$ & $\mathrm{Zn}$ & $\mathrm{Pb}$ & $\mathrm{Cd}$ & $\mathrm{Cr}$ & $\mathrm{NH}_{3}$ & $\mathrm{So}_{2}$ & $\mathrm{Co}^{2}$ & $\mathrm{HCo}^{2}$ & $\mathrm{No}^{2}$ & $\mathrm{Po}^{2}$ & $\mathrm{Ph}$ & $\mathrm{Col}$ & Turb & Temp ${ }^{0} \mathrm{C}$ \\
\hline Thick vegetation & 4.465 & 0.118 & 0.498 & 1.350 & 0.001 & 0 & 0.613 & 0.220 & 0.028 & 1.458 & 0 & 99.125 & 0.137 & 0.084 & 4.100 & 13.500 & 2.153 & 25.375 \\
\hline Commercial & 5.235 & 0.183 & 0.570 & 1.200 & 0.012 & 0 & 0.617 & 0.086 & 0.018 & 1.140 & 0 & 91.250 & 0.083 & 0.045 & 3.975 & 6.500 & 0.665 & 25.550 \\
\hline Peri-urban & 2.340 & 0.057 & 0.280 & 1.450 & 0 & 0 & 0.622 & 0.058 & 0.019 & 1.190 & 0 & 85.500 & 0.090 & 0.057 & 5.550 & 9 & 1.150 & 24.750 \\
\hline Industrial & 3.150 & 0.064 & 0.365 & 1.850 & 0 & 0 & 0.628 & 0.048 & 0.017 & 1.295 & 0 & 76.250 & 0.077 & 0.055 & 4.800 & 15 & 1.950 & 25.750 \\
\hline Low-residential & 8.065 & 0.388 & 1.590 & 1.350 & 0.002 & 0 & 0.628 & 0.395 & 0.027 & 1.330 & 0 & 106.750 & 0.130 & 0.060 & 4.200 & 12.500 & 0.855 & 25.050 \\
\hline High residential & 5.235 & 0.183 & 0.570 & 1.200 & 0.012 & 0 & 0.617 & 0.086 & 0.018 & 1.140 & 0 & 91.250 & 0.083 & 0.045 & 4.700 & 12 & 0.665 & 26.050 \\
\hline Fresh-water & 2.340 & 0.057 & 0.280 & 1.450 & 0 & 0 & 0.622 & 0.058 & 0.019 & 1.190 & 0 & 85.500 & 0.090 & 0.057 & 4.400 & 8 & 1.150 & 25.250 \\
\hline Sparse vegetation & 6.088 & 0.266 & 1.038 & 1.650 & 0.001 & 0 & 0.631 & 0.187 & 0.019 & 1.290 & 0 & 86.417 & 0.092 & 0.060 & 5.052 & 9 & 1.323 & 25.417 \\
\hline WHO standard & $\mathrm{N} / \mathrm{S}$ & $\mathrm{N} / \mathrm{S}$ & $\mathrm{N} / \mathrm{S}$ & $\mathrm{N} / \mathrm{S}$ & $\mathrm{N} / \mathrm{S}$ & $\mathrm{N} / \mathrm{S}$ & $\mathrm{N} / \mathrm{S}$ & $\mathrm{N} / \mathrm{S}$ & $\mathrm{N} / \mathrm{S}$ & $\mathrm{N} / \mathrm{S}$ & $\mathrm{N} / \mathrm{S}$ & $\mathrm{N} / \mathrm{S}$ & $\mathrm{N} / \mathrm{S}$ & $\mathrm{N} / \mathrm{S}$ & 5.6 & 5 & 0.25 & 26 \\
\hline
\end{tabular}

$\mathrm{N}: \mathrm{B}$ the following abbreviations indicate as follows- $\mathrm{Cu}$ (Copper), $\mathrm{Mg}$ (Magnesium), $\mathrm{K}$ (Potassium), $\mathrm{Na}$ (sodium), Zn (Zinc), $\mathrm{Pb}$ (Lead), Cd (Cadmium), Cr (chromium), Ammonia $\left(\mathrm{NH}_{3}\right), \mathrm{So}^{2}$ (Sulfate Ion), $\mathrm{Co}^{2}$ (carbonate Ion), $\mathrm{HCo}^{2}$ (Calcium bicarbonate), N03 ${ }^{2}$ (Nitrate), P04 ${ }^{2}$ (Manganese $\{\mathrm{II}\}$ Phosphate), Col (colour), Turb (Turbidity), Temp (Temperature), N/S (no standard)

\section{Results and Discussion}

In table 2, the physical and chemical characteristics of rain and dew water in the different land uses in Port Harcourt metropolis are displayed. In the table, it is obvious that only $\mathrm{pH}$, colour, turbidity and temperature have WHO standards. As for $\mathrm{pH}$ all - the land use fall below the WHO standards i.e. <5.6. This implies that the rain and dew water across the various land uses are acidic. However, the commercial land use has revealed a higher acidic value of $3.975<6.5$. However, the thick vegetation land use revealed the worse colour of rain water with a value of 13.5>5. This is a strange occurrence; since what is expected is that the vegetal covers would play an ameliorating effect on the rain and dew water colours. However, that is not the case, since most of the illegal mining and refining of petroleum products takes place in these areas. Also the rates of deforestation, due to the urbanization process tend to cause a strain on the vegetal covers; hence the poor colour of rain water in the land-use. 
In terms of turbidity the thick vegetation also has the worst turbidity value of $2.2>0.25$, although rain fall temperature were below the standard across all the land uses investigated. Other pollutant concentration in rain and dew fall was considerably high across the various land uses and is a worrisome development. For example, average copper pollution was as high as $8.065 \mu / \mathrm{gm}^{3}$ while potassium was highest in the low residential land use. Calcium-bicarbonate also recorded the highest value in the high -residential land-use with a value of $106.75 \mu / \mathrm{gm}^{3}$.

The pollution rates are high and very dangerous for rain and dew water quality for many obvious reasons. The first is that these precipitants drops on man, his properties, the vegetal covers (weather the edible or not), and on surface water. Implication is that inhabitants of Port Harcourt metropolis are in danger of the risks associated with these pollutants. On the other hand, the presence of these pollutants in rain and dew water suggests that there is a mixing of rain and dew water in this area due to pollution (Local pollution). However, what was more distributing about this finding is not the fact that there is gross GHGs pollution across the land uses, but that land uses such as fresh water, sparse and thick vegetation, were all highly polluted, indicating that the carbon sinks in the study areas have not been able to reduce the pollutant concentration in air. Nevertheless, this finding agrees with that of Dinrifo et al, (2010), Mackay et al, (2010) who suggested independently in their studies that the diffusion of polluted air, may be more pervasive when the neutralizers of pollutant are reduced (through deforestation) or when there is the presence of the pollutant neutralizer but, the generated emission of toxic gases are higher in concentration than the neutralizers available (vegetation) can handle.

Table 3. Average annual distribution of gases and particulate pollutants across different land-use types in Port Harcourt Metropolis

\begin{tabular}{|c|c|c|c|c|c|c|c|c|c|c|c|}
\hline \multirow[t]{2}{*}{ Land use } & \multicolumn{8}{|l|}{ Gases } & \multicolumn{3}{|c|}{ Particulate matter } \\
\hline & $\mathrm{NO}_{2}$ & $\mathrm{SO}_{2}$ & $\mathrm{CH}_{4}$ & $\mathrm{H}_{2} \mathrm{~S}$ & $\mathrm{NH}_{3}$ & VOCs & $\mathrm{CO}$ & $\mathrm{O}_{3}$ & $\mathrm{PM}_{2.5}$ & $\mathrm{PM}_{10}$ & TSP \\
\hline Thick vegetation & 319.58 & 63.78 & 81 & 425.48 & 46.85 & 77.98 & 66.18 & 132.50 & 106.30 & 396.03 & 600.3 \\
\hline Commercial & 378.40 & 61.15 & 76.55 & 516.25 & 50.65 & 67.10 & 74.45 & 91.45 & 109.80 & 396.95 & 600.3 \\
\hline Peri-urban & 295.40 & 66 & 74.50 & 367.20 & 35 & 47.60 & 61.10 & 94.90 & 47.30 & 364 & 630.3 \\
\hline Industrial & 464.80 & 65.25 & 76.50 & 556.85 & 52.50 & 82.95 & 87.90 & 151.75 & 99.30 & 402.70 & 585.3 \\
\hline Low-r & & 64.25 & 83 & & & 72.95 & & & 101.35 & & 610.3 \\
\hline High residential & 334.15 & 56 & 79.55 & 444.30 & 46.60 & 75.65 & 70.90 & 93.50 & 105.80 & 343.45 & 615.3 \\
\hline Fresh-water & 348.50 & 69.05 & 77.30 & 595.25 & 51.65 & 83.20 & 92.90 & 110.10 & 113.30 & 426.40 & 605.3 \\
\hline Sparse vegetation & 342.27 & 47.20 & 76.20 & 484.37 & 42.58 & 67.95 & 75.85 & 119.78 & 78.7 & 409.37 & 618.13 \\
\hline WHO standard & $\leq 200$ & $\leq 20$ & $\leq 78.72$ & $\leq 200$ & $\leq 37.5$ & $\leq 25$ & $\leq 50$ & $\leq 100$ & $\leq 25$ & $\leq 50$ & $\leq 150$ \\
\hline
\end{tabular}

In table 3, average annual distribution of gases and particulate pollutants across different land-use types in Port Harcourt Metropolis is displayed. In the table one of the first striking things is that all the gases apart from methane gas exceed WHO standards for all the land use types investigated in the metropolis. In terms of $\mathrm{NO}_{2}$ pollution, the industrial land use recorded the highest amount with $464.80 \mu \mathrm{g} / \mathrm{m}^{3}$ while, the thick vegetation recorded the lowest amount with $319.58 \mu \mathrm{g} / \mathrm{m}^{3}$. As for $\mathrm{SO}_{2}$ pollution, all the land uses were exceptionally higher than the WHO standards even the lowest value recorded in the sparse vegetation land use was yet higher than the WHO standard $47.20>20 \mu \mathrm{g} / \mathrm{m}^{3}$. However, for methane gas some 
land uses fell considerably lower than the WHO standard, although the thick vegetation and the low residential and high residential land uses recorded higher methane pollution rates than the WHO standards of 81,83 , and $79.55 \mu \mathrm{g} / \mathrm{m}^{3}$ respectively.

Generally, the other gases display pollution rates that were so high and across all the land uses. For example total suspended particulates were some four times higher than four times the WHO standards. Worrisome is that, in spite of these pollution rates, the activities that bring about these pollutions are on the rise due in part to ignorance and on the other hand greed and the quest to make money. Nevertheless, the land-uses have not posted values that follow the normal scientific assumption. For instance, vegetal covers are known to be sources of clean up for pollutants, yet in this study the area is known to have very high amount of pollutants. Possible reasons for this occurrence include the pollution rates as can also be seen from observation; which are a result of anthropogenic activities that characterize the area (Jayaraman, 2007); urbanization problems (chauhan et al., 2010) and the poor density of the vegetation population due to deforestation (Dominick et al, 2012).

Table 4. The correlation coefficients between air quality parameters and physico-chemical properties of rain and dew water in Port Harcourt Metropolis

\begin{tabular}{|c|c|c|c|c|c|c|c|c|c|c|c|c|}
\hline \multirow{2}{*}{$\begin{array}{c}\text { Water quality } \\
\text { parameters }\end{array}$} & \multirow{2}{*}{$\begin{array}{l}\text { Correlation } \\
\text { parameters }\end{array}$} & \multicolumn{11}{|c|}{ Air quality parameters } \\
\hline & & $\mathrm{NO}_{2}$ & $\mathrm{SO}_{2}$ & $\mathrm{CH}_{4}$ & $\mathrm{H}_{2} \mathrm{~S}$ & $\mathrm{NH}_{3}$ & VOCs & CO & $\mathrm{O}_{3}$ & $\mathbf{P M}_{2.5}$ & $\mathbf{P M}_{10}$ & TSP \\
\hline \multirow{3}{*}{$\mathrm{Cu}$} & $\mathrm{R}$ & 0.73 & -0.56 & 0.45 & 0.35 & 0.64 & -0.57 & 0.76 & 0.54 & -0.58 & 0.69 & 0.74 \\
\hline & Std-div & 1.23 & 0.67 & 1.01 & 1.53 & 1.32 & 2.04 & 0.34 & 2.46 & 1.65 & 2.04 & 1.34 \\
\hline & Sig & 0.01 & 0.04 & 0.05 & 0.05 & 0.00 & 0.01 & 0.00 & 0.03 & 0.02 & 0.01 & 0.00 \\
\hline \multirow{3}{*}{$\mathrm{Mg}$} & $\mathrm{R}$ & 0.54 & -0.86 & 0.59 & 0.47 & 0.74 & -0.65 & 0.75 & 0.34 & -0.63 & 0.78 & 0.63 \\
\hline & Std-div & 1.45 & 1.40 & 0.99 & 0.87 & 2.30 & 2.66 & 2.93 & 2.11 & 2.19 & 2.17 & 1.40 \\
\hline & Sig & 0.04 & 0.00 & 0.03 & 0.04 & 0.00 & 0.00 & 0.30 & 0.07 & 0.00 & 0.00 & 0.00 \\
\hline \multirow{3}{*}{ K } & $\mathrm{R}$ & 0.52 & -0.42 & -0.65 & 0.64 & 0.76 & -0.75 & -0.39 & 0.46 & -0.69 & 0.73 & 0.61 \\
\hline & Std-div & 1.08 & 1.76 & 1.34 & 0.86 & 0.33 & 1.76 & 1.21 & 1.88 & 0.99 & 1.16 & 2.16 \\
\hline & Sig & 0.03 & 0.05 & 0.00 & 0.00 & 0.00 & 0.00 & 0.06 & 0.04 & 0.00 & 0.00 & 0.00 \\
\hline \multirow{3}{*}{$\mathrm{Na}$} & $\mathrm{R}$ & 0.58 & 0.45 & 0.66 & 0.67 & 0.43 & 0.61 & 0.74 & 0.51 & 0.37 & 0.68 & 0.87 \\
\hline & Std-div & 1.43 & 1.22 & 1.35 & 1.10 & 1.68 & 1.95 & 1.01 & 1.54 & 1.20 & 1.40 & 1.04 \\
\hline & Sig & 0.00 & 0.03 & 0.00 & 0.00 & 0.00 & 0.01 & 0.00 & 0.00 & 0.06 & 0.00 & 0.00 \\
\hline \multirow{3}{*}{$\mathrm{Cd}$} & $\mathrm{R}$ & 0.71 & -0.52 & 0.66 & 0.35 & 0.69 & -0.61 & 0.71 & 0.54 & -0.58 & 0.69 & 0.70 \\
\hline & Std-div & 1.03 & 0.64 & 1.47 & 1.53 & 1.45 & 2.04 & 4.01 & 2.46 & 1.33 & 2.04 & 1.34 \\
\hline & Sig & 0.00 & 0.01 & 0.00 & 0.05 & 0.00 & 0.00 & 0.00 & 0.03 & 0.02 & 0.01 & 0.00 \\
\hline \multirow{3}{*}{$\mathrm{Cr}$} & $\mathrm{R}$ & 0.56 & -0.66 & 0.59 & 0.47 & 0.72 & -0.60 & 0.72 & 0.34 & -0.63 & 0.78 & 0.61 \\
\hline & Std-div & 1.41 & 1.42 & 2.97 & 0.87 & 2.30 & 2.65 & 2.00 & 2.11 & 2.19 & 2.17 & 1.40 \\
\hline & Sig & 0.02 & 0.00 & 0.00 & 0.04 & 0.00 & 0.00 & 0.00 & 0.07 & 0.00 & 0.00 & 0.00 \\
\hline \multirow{3}{*}{$\mathrm{NH}_{3}$} & $\mathrm{R}$ & 0.54 & -0.47 & -0.65 & 0.64 & 0.71 & -0.79 & -0.58 & 0.46 & -0.69 & 0.73 & 0.61 \\
\hline & Std-div & 1.18 & 1.70 & 1.34 & 0.86 & 1.45 & 2.70 & 1.11 & 1.63 & 2.09 & 1.16 & 2.06 \\
\hline & Sig & 0.00 & 0.05 & 0.00 & 0.00 & 0.00 & 0.00 & 0.06 & 0.04 & 0.00 & 0.00 & 0.00 \\
\hline \multirow{3}{*}{$\mathrm{So}_{2}$} & $\mathrm{R}$ & 0.54 & 0.45 & 0.66 & 0.67 & 0.43 & 0.61 & 0.74 & 0.51 & 0.37 & 0.68 & 0.87 \\
\hline & Std-div & 1.42 & 1.22 & 1.35 & 1.10 & 1.68 & 1.23 & 1.01 & 1.54 & 1.20 & 1.40 & 1.04 \\
\hline & Sig & 0.01 & 0.03 & 0.00 & 0.00 & 0.00 & 0.01 & 0.00 & 0.00 & 0.06 & 0.00 & 0.00 \\
\hline \multirow{3}{*}{$\mathrm{Co}^{2}$} & $\mathrm{R}$ & 0.70 & -0.56 & 0.45 & 0.35 & 0.54 & -0.86 & 0.59 & 0.47 & 0.74 & -0.65 & 0.75 \\
\hline & Std-div & 1.20 & 1.60 & 1.01 & 1.53 & 1.45 & 1.40 & 0.99 & 0.87 & 2.30 & 2.66 & 2.93 \\
\hline & Sig & 0.00 & 0.04 & 0.05 & 0.05 & 0.04 & 0.00 & 0.03 & 0.04 & 0.00 & 0.00 & 0.00 \\
\hline \multirow{3}{*}{$\mathrm{HCo}^{2}$} & $\mathrm{R}$ & 0.50 & -0.81 & 0.59 & 0.47 & 0.52 & -0.42 & -0.65 & 0.64 & 0.76 & -0.75 & -0.39 \\
\hline & Std-div & 1.02 & 1.42 & 0.99 & 0.87 & 1.08 & 1.76 & 1.34 & 0.86 & 0.33 & 1.76 & 1.21 \\
\hline & Sig & 0.00 & 0.01 & 0.03 & 0.04 & 0.03 & 0.05 & 0.00 & 0.00 & 0.00 & 0.00 & 0.06 \\
\hline \multirow{3}{*}{$\mathrm{No}^{2}$} & $\mathrm{R}$ & 0.59 & -0.42 & -0.65 & 0.64 & 0.58 & 0.45 & 0.66 & 0.67 & 0.43 & 0.61 & 0.74 \\
\hline & Std-div & 1.21 & 1.72 & 1.34 & 0.86 & 1.43 & 1.22 & 1.35 & 1.10 & 1.68 & 1.95 & 1.01 \\
\hline & Sig & 0.00 & 0.04 & 0.00 & 0.00 & 0.00 & 0.03 & 0.00 & 0.00 & 0.00 & 0.01 & 0.00 \\
\hline \multirow{3}{*}{$\mathrm{Po} 4^{2}$} & $\mathrm{R}$ & 0.54 & 0.47 & 0.68 & 0.64 & 0.59 & 0.69 & 0.71 & 0.54 & 0.55 & 0.62 & 0.82 \\
\hline & Std-div & 1.32 & 1.33 & 1.13 & 1.11 & 2.68 & 1.43 & 1.55 & 1.50 & 1.25 & 1.48 & 1.34 \\
\hline & Sig & 0.01 & 0.05 & 0.00 & 0.00 & 0.00 & 0.00 & 0.09 & 0.00 & 0.06 & 0.00 & 0.00 \\
\hline
\end{tabular}


$\mathrm{N}$ :B the following abbreviations indicate as follows- $\mathrm{Cu}$ (Copper), $\mathrm{Mg}$ (Magnesium), $\mathrm{K}$ (Potassium), $\mathrm{Na}$ (sodium), Zn (Zinc), Pb (Lead), Cd (Cadmium), Cr (chromium), Ammonia $\left(\mathrm{NH}_{3}\right), \mathrm{So}^{2}$ (Sulfate Ion), $\mathrm{Co} 3^{2}$ (carbonate Ion), $\mathrm{HCo}^{2}$ (Calcium bicarbonate), N03 ${ }^{2}$ (Nitrate), $\mathrm{P}^{2} 4^{2}$ (Manganese $\{$ II $\}$ Phosphate), Col (colour), Turb (Turbidity), Temp (Temperature), N/S (no standard), Ph ( Potential of Hydrogen)

$\mathrm{N}: \mathrm{B}: \mathrm{n}$ for these correlations is 52 .

In table 4 , the correlation coefficients between air quality parameters and physicochemical properties of rain and dew water in Port Harcourt Metropolis is displayed. From the table we can deduce that there is a strong positive correlation between the pollutant concentration observed in rain and dew water and the observed relative humidity in the area at $P>0.05$. This also reflects that the models are statistically significant, however at varying magnitudes looking at the co-efficient of determinations. Also, the standard deviations are low revealing the relatively small differences between the data sets all year round.

\section{Conclusion}

This study examined the relationships between properties of atmospheric precipitates (rain and dew water) and emitted GHGs across the different land use types in Port Harcourt metropolis. Using some empirical measures the study was able to find out that port-Harcourt was much polluted with greenhouse gases and particulate matters which were also much beyond the standard of world health organisation (WHO). These gases were also found to be a major cause of pollution in rain and dew water; which are by this study found to be very acidic and as such are harmful to man and his environment. As a result, the study concludes that adequate steps need to be taken urgently to cushion the menace of rain and dew water pollution resulting from GHGs pollution in the study area.

\section{Recommendations}

As a result of the findings of this study, the following are recommended

a) There is need for local inhabitants of Port-Harcourt metropolis to imbibe the use of protective gadgets, such as nose mask and eye glasses, when engaged in outdoor activities, whether working, taking a stroll or making a trip within the city. This will protect the body in the following ways; a) protects the eyes from ingesting the pollutant concentration which can lead to health problems such as itching, partial blindness, or even total blindness, ii) protect the lungs from being supplied with polluted air which may present humans with very serious health problems.

b) Locals are by this medium advised to avoid any body contact with precipitates (whether in dew or rain form) in port-Harcourt metropolis and in the adjoining areas; especially, when such a person is not near home which presents the luxury of being able to bath immediately. This is because the study found that the rain and dew water contents in the area are not only acidic, but could be harmful to the skin.

c) In the very poor areas such as Makoba and Eleme, where rain water is still used for domestic purposes, locals are advised to take the following precautions; i) boil the 


\section{Macrothink}

Environmental Management and Sustainable Development

ISSN 2164-7682

2019, Vol. 8, No. 4

rain water and possibly add chlorine before ingesting the water, ii) use antiseptics on the water before using such to bath.

d) There is the need for the establishment of air quality data collection stations from where information on air quality characteristics can be collected daily. The need for this is that there will be not only a broad data bank of air quality characteristics, but will also provide insights into the state of the environment from time to time. More so there is need to reuse the flared gas in the area by converting them into useable energy.

\section{References}

Beysens D., Lekouch, I., Mileta, M., Milimouk, I., \& Muselli, M. (2009). Dew and Rain Water Collection in South Croatia. International Journal of Civil and Environmental Engineering, 1(2), 64-70.

Beysens, D., Ohayon, C., Muselli, M., \& Clus, O. (2006). Chemical and biological characteristics of dew and rain water in an urban coastal area (Bordeaux, France). Atmospheric Environment, 40(2), 3710-3723. https://doi.org/10.1016/j.atmosenv.2006.03.007

Chauhan, A., Powar, M., Kumar, R., \& Joshi, P. C. (2010). Assessment of ambient air quality status in urbanization, industrialization, and commercial centers of Uttarakhant (India). Journal of American Science, 6(9), 565-568.

Dinrifo, R. R., Babatunde, S. O. E., Bankole, Y. O., \& Demu, Q. A. (2010). PhysicoChemical Properties of Rain Water Collected from Some Industrial Areas of Lagos State Nigeria. European Journal of Scientific Research, 41(3), 383-390

Dominick, D., Latif, M. T., Juahir, H., Aris, A. Z., \& Zain, S. M. (2012). An assessment of influence of meteorological factors on PM10 and $\mathrm{NO} 2$ at selected stations in Malaysia. Sustainable Environment Research, 22(5), 305-315.

Efe, S. I. (2009). A comparative study of the physiologic comfort of Sapele, Warri and Onitsha of Nigeria. Ilorin Journal of Business and Social Sciences, 13(2), 152-162.

Efe, S. T. (2002). Urban warming in Nigeria cities. The case of Warri Metropolis. Afr. J. Environ., 2(2), 6.

Efe, S. T., Ogban, F. E., Horsfall, M. Jnr, \& Akporhonor, E. E. (2005). Seasonal Variation of physico-chemical characteristics in water resources quality in Western Niger Delta Region, Nigeria. J. Appl. Sci. Environ. Mgt., 9(1), 191 - 195.

Eludoyin, O. S., \& Akinola, O. (2015). Spatio-temporal Analysis of Wetland Change in Port Harcourt Metropolis. Tanzania Journal of Science, 41, 48-63.

Eludoyin, O. S., Oderinde, F. A., \& Azubuike, O. J. (2013). Heavy metals concentration under rubber plantation (Hevea brasiliensis) in Hydromophic Soil of South-south Region of Nigeria. Ife Research Publications in Geography (IRPG), 12(1 \& 2), 107-119.

Fessehaye, M., Abdul-Wahab, S. A., Savage, M. J., Kohler, T., Gherezghiher, T., \& Hurni, H. 


\section{Macrothink}

Environmental Management and Sustainable Development

ISSN 2164-7682

2019, Vol. 8, No. 4

(2014). Fog-water collection for community use. Renew. Sustain. Energy Rev., 29, 52-62. https://doi.org/10.1016/j.rser.2013.08.063

Jayaraman, G. (2007). Seasonal variation and dependence on meteorological condition of roadside suspended particles/pollutants at Delhi. Environmental Science, 2(2), 130-138.

Kidron, G. J., \& Starinsky, A. (2012). Chemical composition of dew and rain in an extreme desert (Negev): cobbles serve as sink for nutrients. Journal of Hydrology, 57, 284-291. https://doi.org/10.1016/j.jhydrol.2011.12.014

Mackay, D. S., Ewers, B. E., \& Loranty, M. M. (2010). On the representativeness of plot size and location for scaling transpiration from trees to a stand. Journal of Geophysical Research-Biogeosciences, 115(2), 1-14. https://doi.org/10.1029/2009JG001092

Mmom, P. C., \& Fred-Nwagwu, F. W. (2013). Analysis of Landuse and Landcover Change around the City of Port Harcourt, Nigeria. Global Advanced Research Journal of Geography and Regional Planning, 2(5), 076-086.

Singh, G. K., Rao, D. K., \& Khan, M. G. M. (2014). Calibration Estimator of Population Mean in Stratified Random Sampling. Computer Science and Engineering (APWC on CSE). 2014 Asia-Pacific World Congress on 4-5 November, 2014, 1-5.

https://doi.org/10.1109/APWCCSE.2014.7053875

United Nations Environment Programme (UNEP) (2009). Rainwater Catch it While You Can: A Handbook on Rainwater Harvesting in the Caribbean. Prepared by the Caribbean Environmental Health Institute. 55P

Vuollekoski, H., Vogt, M., Sinclair, V. A., Duplissy, J., Järvinen, H., Kyrö, E. M., ... Kulmala, M. (2015). Estimates of global dew collection potential on artificial surfaces. Hydrol. Earth Syst. Sci., 19, 601-613. https://doi.org/10.5194/hess-19-601-2015

Weli, V. E. (2014). Atmospheric Concentration of Particulate Pollutants and its Implications for Respiratory Health Hazard Management in Port Harcourt Metropolis, Nigeria. Civil and Environmental Research, 6(5), 11-17.

Xu, Y., Zhu, H., Tang, J., \& Lin, Y. (2015). Chemical Compositions of Dew and Scavenging of Particles in Changchun, China. Advances in Meteorology, 2015, 1-11.

https://doi.org/10.1155/2015/104048

\section{Copyright Disclaimer}

Copyright for this article is retained by the author(s), with first publication rights granted to the journal.

This is an open-access article distributed under the terms and conditions of the Creative Commons Attribution license (http://creativecommons.org/licenses/by/3.0/). 